\title{
Labor Reform in Mexico, Analysis of Principal Changes and Method of Recruitment
}

\author{
Martín Álvarez Ochoa, Sergio Felipe López Jiménez, \\ Héctor Rodríguez Herrera, Teodoro Reyes Fong, Georgina Govea Valencia \\ University of Colima, Colima, Mexico
}

\begin{abstract}
Actually, the country's development aims to achieve higher levels of productivity, so it had to adapt to international standards. This has served to ease the hiring of both operational and managerial controls, giving emphasis on training and allowing the pairing boss-worker to take the productivity like benchmark. The labor reform allows companies to make changes with their workers; such changes must be reflected in lower costs for businesses, by labor input and increased competitiveness, however, two years ago this guideline was implanted and society asks if the results are congruent, because Mexican society is undergoing economics problems issue as well as a deficit in generating jobs. Therefore, analyzing whether modifications made to the federal labor law (FLL) are designed to optimize safety of workers and enterprises in which they work is the subject of this research. The corresponding analysis was performed using the deductive method.
\end{abstract}

Keywords: federal labor law (FLL), procurement, productivity, economic impact

\section{Introduction}

Since its creation, the fundamental scoop of the federal labor law (FLL) has been the protection of workers. In labor law, a curious phenomenon occurs, because without being regulated some aspects, companies already labored for hours and reduced week, and in big cities tele-working were quite common and currently with the labor reform in 2012 aiming to standardize this series of works that are not even included in this regulation (De Buen, 2004).

However, the analysis made in this paper is to determine the characteristics of those employments of the previous century and to thereby identify the major changes that have taken the labor group and organizations since two years of his implementation, and know how they are complying with their respective obligations.

The questions to which this paper intended to provide clarity are: (a) What is the main effect of the

Martín Álvarez Ochoa, Ph.D. in Tax, School of Accounting and Administration of Colima, University of Colima, Colima, Mexico.

Sergio Felipe López Jiménez, Ph.D. in Strategic Planning and Management Technology, School of Accounting and Administration of Colima, University of Colima, Colima, Mexico.

Héctor Rodríguez Herrera, Master in Tax, School of Accounting and Administration of Colima, University of Colima, Colima, Mexico.

Teodoro Reyes Fong, Ph.D. candidate, School of Accounting and Administration of Colima, University of Colima,Colima, Mexico.

Georgina Govea Valencia, Master in Finance, School of Accounting and Administration of Colima, University of Colima, Colima, Mexico.

Correspondence concerning this article should be addressed to Martín Álvarez Ochoa, Av. Universidad 333, Colonia Las Víboras, C.P. 28040, Colima, México. E-mail: alvarezochoa@ucol.mx. 
changes made in 2012 to FLL? (b) What is the expected effect on jobs that for many years was not covered by the FLL? (c) What is the financial impact of labor reform in companies?

So far, the labor reform has not produced the expected benefits, so it is necessary that economic actors make a major effort to complete the reform and thereby increase the competitiveness and efficiency (Herrera, 2014).

\section{Problem Approach}

Mexico is currently in a period of political and economic restructuring with the vision to create higher productivity and global competitiveness. Since labor reform is approved, companies have undergone a number of changes with their workers; however, they must consider its impact on the legal, economic, and social spheres. Therefore, it's important to note that with the changes made to the FLL, the intention is to optimize the security of workers and enterprises in which they work. The business sector of the country believes that it's important to adapt to these changes to stay competitive in the market, so the FLL should be applied to establish the rights and obligations generated for the boss and employee.

As relates to the financial framework, problems may arise in the short, medium, and long term, generating changes in lifestyles, and consequently, economic disruption. The reform aims to boost the economy for companies to stabilize and give better opportunities for workers, arguing for greater competitiveness and productivity, minimizing costs and maximizing profits for the company, leading to an assumption that an increase in contributions will be obtained by lowering the deductions of both businesses and individuals.

Moreover, there are repercussions that directly and indirectly affect the human capital of the company, first of which is the breaking of the principle of bilateralism between employee-boss and job stability, causing dismissals without cost to the boss and leaving the boss rescind of the employee during the test period and initial training, without having a higher cost than that exists in the law of 1973. Undoubtedly, the amendment to the law and the flexibility to hire people require that the boss and the Ministry of Labor and Social Forecast (STPS) keep track of the performance and worker productivity during this period. Hence, the desire to do a thorough analysis on the impact entails the labor reform.

\section{Explanatory Statement of Labor Reform}

Today, Mexico is considered in the group of countries of the OECD (Organization for Economic Cooperation and Development), who expressed the urgent need to give people quality jobs, for which they should promote structural reforms in adherence principles and basic labor rights (Maihold, 2012).

Therefore, the labor reform, approved in November of 2012 and based on a draft prepared by the Employers' Confederation of the Mexican Republic (COPARMEX), seeks to meet the purposes of the OECD - promote the creation of more jobs and make those working relationships develop in informality, regularize, and transit the formal market (CEPAL/OIT, 2012).

Mexico participates in different international organizations and has had to establish changes to evolve in the workplace and not to be marginalized, so reason for labor reform was created that would mean losing competitiveness in economy and leaving out of the global environment.

That is why the federal government listed a number of objectives achieved with amendments and additions to the FLL, which are mentioned below:

(1) ensuring decent work, contributing to respect for human dignity of workers; non-discrimination on grounds of gender, sexual orientation, disability, race or religion; access to social security; remunerative salary 
and training; safety and health at work; freedom of association; autonomy and union democracy; the right to strike and collective hiring;

(2) including laws that promote training periods and circumstances of privation of work; strengthening accountability by the union;

(3) managing the outsourcing in order to prevent evasion and avoidance of compliance with obligations of the employer;

(4) criminalizing work under 14 outside the family circle; providing greater protection and legal certainty for Mexicans working with foreign governments;

(5) rethinking means of communication between boss and employee in order to ensure advance notice of termination of employment; including a new cause for termination of employment without liability for acts, conduct, or behavior that undermine or violate their dignity;

(6) giving priority to productivity as the main standard for access to permanent vacancies or temporary spaces, rather than seniority, establishing a professional service of special job for the hiring, promotion, retention, and performance evaluation;

(7) avoiding the negative implications of a prolonged duration of labor disputes or "strikes"; on the other hand, giving cause for lack of a strike, if the union does not comply with these statutes, increasing the penalty for persons who violate the provisions.

\section{Principal Changes in the FLL}

Improving competitiveness, productivity, generation of formal employment, working relationships with equity, equality and non-discrimination, modernizing labor justice, and best practices in union affairs, are the reasons that led to a labor reform, in the great changes which are immersed but are not entirely satisfactory. That is why the object of study is to analyze those issues that impact the business sector.

In the Political Constitution of the Mexican United States of 1917, Article 123 refers the right to a dignified and decent work, where the Union Congress publishes the laws governing the employment contracts of the workers, laborers, employees, domestic, and craftsmen, in order to support and protect the people, giving them the opportunity to demand a worthy or decent work.

The definition of dignified and decent work can be found in Article 2 of the FLL of 1970 and the nature of working conditions in the Article 3. The intention of these articles is that there isn't discrimination based on gender, sexual preference, disability, race, or religion. Optimum health and safety risks are established to prevent work and respect freedom of association; prevent autonomy and union democracy; prevent the right to strike and collective bargaining, access to social security and receive ongoing training to increase productivity and worker welfare.

Both articles defend this right to dignified and decent work for individuals, as well as those generated obligations for companies, fostering a better quality of life of workers and delivering business benefits in production, because their workers will get an incentive to better job performance.

Another important point in the reform is minors, the bumper is 14 years, for those who don't meet this requirement need family protection and enjoy their constitutional rights to education and health rights, among others. Article 22-B specifies the standards for hiring of this segment.

In this regard, companies should be alert to the regulations and the opinions of the courts in order to avoid missing opportunities, but neither fall into irregularities that may cause costs to increase. Explicitly is 
prohibited to employ children under 14 , unless they are relatives to the second degree, in ascending or descending order. The penalties range from 250 to 5,000 times the minimum salary in the geographical area where they are located and one to four years in jail, also to be given equal treatment for equal work, because the employer shall reinstate the unpaid.

As a new paternity leave by birth and adoption, five days with pay is recognized with working men on the birth of their children and likewise in cases of adoption of an infant. A form of hiring, benefiting, and giving legal certainty for both the employer and the employee is recognized, so that adequate time to develop the knowledge and skills is necessary for the job that has been assigned, and on the other hand, the boss may at any time verify whether it meets the quality requirements.

If an employee was recently contracted or the work was not yet fulfilled in a period of 180 days in the company, the law provides that the test period is maximum 30 days (except the cases such as executives, managers, or professionals specialized in which this period can be up to 180 days under Article 39-A) and can't be extended or postponed.

The salary and benefits shall be given according to the category or job held by the worker at the end of the period; the employee is required to demonstrate that they have acquired the skills agreed in the contract. It is noteworthy that although to date these haven't been created by the National Productivity Institute, the agency will be responsible for validating the comments and objections made by the employer based on the report, if the case of warrants decides to end working link without liability for the payment of benefits. The definition of training developed by Siliceo (2004), which literally says "The training is planned and based on real needs of a company or organization oriented towards a change in knowledge, skills, and attitudes of partner activity", helps to better understand this topic. This type of contract aims to evaluate the results of the test period, which is recommended when an employee is assigned to new activities.

Article 39-B of the FLL, which focuses on regulating training contracts, provides that upon completion of the initial training period (which has a maximum duration of three months), the employee must prove to the employer that he has the necessary knowledge to perform his job, otherwise, the employer may terminate the employment relationship without liability.

The training and testing periods are also regulated by Articles 39-C, 39-D, and 39-E, which specify that there must be formal writing and social security of these contractual arrangements, otherwise, the workers will have a permanent contract. Test periods and initial training can't be applied simultaneously or successively to the same worker, or can be applied in more than one occasion, even for different positions, promotion, or other employment with the same employer.

Among the rights of the boss include the followings: subjecting a worker to initial training contract or a contract test period, if it complies with the requirements set by law; having people trained to perform their duties as a result of using these types of contracts; determining if the term of probation or initial training the worker has requirements and knowledge needed to be in the position for which it was so. Breaking employment relationship if the results of the test period or initial training have not been satisfactory for him determines compliance with labor standards unilaterally.

Additional obligations of employers are not subject to worker over a period of 30 days to test, except for the cases specified by law; not to subject the employee to initial training over six months, except for cases provided by law; registering in the Mexican Social Security Institute, specifying the type of contract in which it's immersed (probation or initial training); and determining the time during which the employee will be 
subject to the employment relationship. Otherwise, the worker and the law can understand that this is done by indefinite time. During the testing period or initial training, the payment of salary to the worker under the position is held.

Throughout the testing period or initial training, it will be given to the employee benefits as set by law, taking into account the opinion of the Joint Commission on productivity, training, and skills in terms of FLL for purposes of terminating the employment relationship at the end of the testing period or initial training (Ministry of Labor and Social Welfare, 2013), and to the worker in case of termination of employment, otherwise, recruitment is considered indeterminate.

Workers who are on testing for only 30 days or initial training, except the cases in the law, have the right to: (a) be subject to initial training and probation for once, without this it can be successive or simultaneous in any case, (b) enjoyment of salary, (c) ensure social security, and (d) benefit because of the category or work performed. In case of obtaining an indefinite contract, testing periods and initial training will be considered as generators old. Moreover, the obligations that workers acquire during this period are: (a) When they finished the testing period, they must demonstrate to the employer that they have possessed the knowledge required for the job and (b) they must accept the opinions of the boss, if given for terminating the employment relationship.

A third way to hire is by season, which was already used before, but is now regulated. This is applicable to those employees who work in companies whose nature does not allow them to have steady activities throughout the year (December periods, holiday periods, harvest time, etc.). In this type of contract, the period for which the employee will work and the end of this time the employment relationship shall be suspended must be agreed. There is also the possibility of negotiating contracts for days, weeks, or months and workers have the same rights as workers indefinitely, as provided in Article 39-F, in proportion to the time worked in each period.

It can be noted that this mode allows the employee to maintain a status with the rights and obligations under the FLL for ordinary workers or indefinitely, even if these work only at certain times or seasons. Upon suspension employment, also the relationship ends.

Another type of contract is related to tele-work, whose regulation is referred to in Article 311 of the FLL, which establishes that tele-working is one done remotely using information technology and communication in the place where the employee chooses, without vigilance or immediate direction of his boss. According to Buira (2012), tele-work is the way of work done in a place away from the central offices or usual workplaces involving the use of computers and telecommunications, where such tools are essential to meet the activities.

This type of work is a disadvantage for the company, because it is geographically separated from its workers and can't supervise their performance; while on the other hand it has advantages that are a major benefit for not being a worker in the company and it creates in these optimized workspaces and some more convenience and savings in fixed costs.

Among the adjustments made to the FLL on contracts, payment of salary contemplated per unit time, unit building salary, and wages. Article 83 has been extended and mentioned that if using this method, that nature must be specified in the contract. This officially allows generating jobs for a few hours, prohibiting the worker to receive the wage in a day less than the minimum, even if it isn't a working day of eight hours, and further prohibiting them to work more than eight hours regardless of whether they are paid by hour. Employees, who are in this mode, should have the labor and social security rights under their corresponding position which they hold. 
Article 83 also provides that when the salary is per unit of work, this aspect must be specified in the contract, as well as the quantity and quality of the material, tool status and useful things, where appropriate, providing for running the work and the time available to the worker. Not so, the boss may require the employee to pay the natural tool wear resulting from work.

Compared to the previous point, recognizing hourly earnings, or testing periods and grant benefits, which years ago did not happen because employers did not register with the social insurance to these workers, there is no doubt to make the corresponding record which will have to register also in the Tax Administration Service (SAT) and through the Federal Taxpayers Registry (RFC) will have higher withholding tax on income from wages and therefore higher revenues (Mayoral, 2013).

Moreover, the Board of Conciliation and Arbitration (JCA) and courts in Mexico have adopted a protectionist attitude towards workers, which is a concern for the Mexican business sector (chiefs), because for many years, dissatisfied employees have abused of the judicial system to prolong litigation and earn wages. These salaries were unlimited and the boss should cover them until he turned the sentence imposed on him in an opinion or even to reinstate the dismissed employee in his job. Therefore, labor trials could trigger millions of convictions.

The master De la Cueva (1998) defined the vanquished or fallen salaries as those who should receive the worker if he had developed normally working relationship from the date he was fired or from that labor wages fault of the boss was broken, until the award that ordered that the reinstatement or payment of compensation should be supplemented. In this sense, the reform puts a stop to this provision. Now, the maximum amount that can be generated by this concept is of one year and could only update some interest ( $2 \%$ of the amount of 15 months' salary).

The main argument is to combat this limit in the proceedings and it would represent a violation of the principle of stability in employment, because even a damning award requiring to the boss to reinstate a worker is obtained, this order does not represent respect for the rights of ceased considering that despite what the law says, any labor case is solved in less than one year.

\section{Salaries Due or Overdue}

As relates to salaries due or overdue, the FLL referenced in the following articles: Article 48 argues that the worker may apply to the Board of Conciliation and Arbitration, reinstated in the work performed, or compensated with the amount of three months' salary; Article 49 says that the employer shall be exempted from the obligation to reinstate the worker, upon payment of compensation determined in Article 50 in the following cases:

(1) If the employment relationship was retail particular time of year, in an amount equal to the total of wages than half the length of service; if it exceeds one year, in an amount equal to the total of salaries of six months for the first year and 20 days for each of the following years he had served;

(2) If the employment relationship is indefinite, the compensation shall consist of 20 days salary for each year of service offered;

(3) In addition to the allowances referred to the previous sections, in the amount of three months' salary and the salaries are due from the date of dismissal until the claims are paid wages.

\section{Training and Productivity}

Globally, the training of human resources is the answer to the need for companies with qualified and productive staff. Obsolescence is also one of the reasons why the institutions are concerned with training 
human resources, as it seeks to update their knowledge with new techniques and working methods that ensure efficiency and effectiveness. For companies or organizations, training of human resources must be vitally important, because it contributes to personal and professional development of individuals, while resulting in benefits for the company (León, 2012).

In the labor reform, contemplated important aspects are related to this topic, which can be found in Article 153-A of the FLL. This article talks about the obligation of employers to provide all employees and those to receive training in their work to enable it to raise their standard of living, employment competition, and productivity, according to plans and programs formulated in common agreement by the employer and the union or most of their workers. To offer training and comply with the law, it can train workers outside or inside of the company, either by the own staff or by instructors who are specially hired for this purpose.

It should take into account that the specialist staff training must be approved and registered with the Secretariat of Labor and Social Welfare (STPS). Training will be imparted to the employee during the hours of their working day, unless the boss and the employee agree that imparts as well. In the event that the worker wishes to train in a different occupation performed daily, training will take place outside working hours.

\section{Benefits of Training in the Companies}

The benefits of training are numerous, among the main ones are: (1) leading to higher profitability and more positive attitudes, (2) improving the knowledge of the position at all levels, (3) creating better image, (4) improving the chiefs-subordinate relationship, (5) increasing staff motivation, which brings consequently higher productivity, (6) promoting communication throughout the organization, (7) reducing stress and allowing the management of areas of conflict, (8) decision making and problem solving streamlines, (9) fostering development for promotion, (10) contributing to the formation of leaders and executives, and (11) decreasing conflicts as a result of more skilled people existing in companies.

However, in Mexico there is an ongoing review by the fact that several changes described in this reform violate the individual rights of the political constitution of the Mexican United States, arguing that the amendment brings instability in jobs, cancels the bilateral employers-chief in the labor relations, prevents workers generate seniority, reduces back pay, cheaper labor, and suppresses almost all obligations of the boss give him through outsourcing regulation and new forms of hiring, which together only result in more poverty to the general population (Lóyzaga, 2013).

\section{Conclusions}

As a result of major changes, it provides business benefits to both employees and employers, creating an employment relationship more attached to the convenience of both parties as subjects within an organization. The changes are mainly focused on creating more quality jobs, classified in terms of the same law as dignified and decent work. This term can be considered as a pillar of the reform, which includes other changes such as contractual rules and regulations thereof, the annex to paternity leave, hourly work and building work, tele-work regulation, and rights now covered by seasonal work.

The contractual arrangements implemented in the new labor reform allow the generation of formal jobs; this happens for the ease of hiring and regulation of existing forms. By applying the methods of recruitment, it supports the company, so this factor gives the boss assertiveness to create more employment relationships. 
Likewise, companies need workers with certain skills to perform specific tasks, so that training is a key factor when hiring a person, and moreover, to measure the level of effort of employees. With respect to the initial training, it's observed that the costs of implementing such activity are high relative to the benefit that could be obtained in the short-term, i.e., at the end of the training period, the employer may terminate the employment relationship and the investment fails to recover.

The labor reform includes new rights and obligations, creating a balance in chief-employee link, which benefits both parties and strengthens the employment relationship.

The changes that directly affect the organization are primarily social, economic, and legal nature, which are linked together. With these updates, employees are benefited by the principles to enforce individual rights, employers for the facilities they have to hire people, and the national economy by creating new jobs.

Undoubtedly, the changes made to the FLL are generating an economic impact that is reflected in finance companies. The most important changes in labor reform are the changes in the payment of wages due to labor rescission, which is reduced to one year, representing lower costs for businesses as well as regulation of tele-work that optimizes the company costs and spaces.

\section{References}

Buira, J. (2012). El teletrabajo entre el mito y la realidad (Telework between myth and reality). Barcelona: UOC.

CEPAL/OIT. (2012). Coyuntura laboral en América Latina y el Caribe (The employment situation in Latin America and the Caribbean). Retrieved from www.obela.org/system/files/Cepal_CoyunturaLaboralOctubre2012AL.pdf

De Buen, N. (2004). Derecho del Trabajo (Labour law). México: Editorial Porrúa.

De la Cueva, M. (1998). El Nuevo Derecho Mexicano del Trabajo (The new Mexican labor law). México: Editorial Porrua.

Herrera, E. (2014). Empresas no ven beneficios en reforma laboral (Companies do not see benefits in labor reform). Retrieved from http://www.milenio.com/region/Empresas-ven-beneficios-reforma-laboral_0_259774065.html

León, R. Y. (2012). Importancia de la Capacitación del Personal en las Utilidades de la Empresa (Importance of training staff profit company). Retrieved from http://www.gerenciayempresa.com/documentos/articulos/IMPORTANCIA_DE_LA_ CAPACITACION.pdf

Lóyzaga, O. (2013). Los grandes retrocesos de la reforma laboral (The major setbacks of labor reform). Retrieved from http://www.elcotidianoenlinea.com.mx/pdf/17807.pdf

Maihold, G. (2012). El G-20 y el Nuevo Orden Internacional (The G-20 and the new international order). México: Los cuadernos de la Cátedra Humboldt del Colegio de México.

Mayoral, I. (2013). Impuestos castigarán al empleo en México (Taxes punish employment in Mexico). Retrieved from http://www.cnnexpansion.com/economia/2013/11/29/incertidumbre-laboral-frena-el-empleo

Ministry of Labor and Social Welfare. (2013). Constitution of the joint committee on training, instruction and productivity for companies with over 50 employees. Retrieved from http://www.stps.gob.mx/bp/secciones/conoce/areas_atencion/areas_ atencion/inclusion_laboral/capacitacion/comision_mixta_capacitacion.html

Siliceo, A. A. (2004). Capacitación y Desarrollo de Personal (Training and staff development). México: LIMUSA. 